\title{
Reflections about abortion limitation
}

\author{
Reflexões sobre a limitação do aborto
}

Andrea Cioffi (https://orcid.org/0000-0001-5163-9558) ${ }^{1}$

Fernanda Cioffi (https://orcid.org/0000-0001-6685-3231) ${ }^{2}$

Raffaella Rinaldi (https://orcid.org/0000-0001-9222-2978) ${ }^{1}$

${ }^{1}$ Department of Anatomical, Histological,

Forensic and Orthopaedic Sciences, Sapienza

University of Rome. Viale Regina Elena, 336, 00161. Rome Italy.

an.cioffi19@gmail.com

${ }^{2}$ Fertilitas Day Surgery

Reproductive Medicine.

Salerno Italy.

\begin{abstract}
The debate on abortion has not yet found a clear solution. In fact, there is still discussion about what the limits of this procedure should be. This uncertainty is related to the lack of a clear definition of human life: when can the product of conception be defined as a human being with full medical-legal rights? Based on the answer to this question, the various world governments have drafted more or less restrictive laws regulating abortion. Since May 2019, some American states have considerably restricted the possibility of carrying out abortion on their territory. Alabama has practically banned abortion in any circumstance (including incest and rape). Obviously, these restrictive policies have had a significant impact on the social, bioethical and legal debate, concerning abortion, globally. This paper analyses the implications of these policies with a focus on women's fundamental rights: the right to health and the right to self-determination.
\end{abstract}

Key words Abortion, Abortion restriction, Health policy, Women, Fetus
Resumo $O$ debate sobre o aborto ainda não encontrou uma solução clara. Na verdade, ainda há discussão sobre quais devem ser os limites deste procedimento. Esta incerteza está relacionada com a falta de uma definição clara da vida humana: quando pode o produto da concepção ser definido como um ser humano com plenos direitos médico-legais? Com base na resposta a esta pergunta, os vários governos mundiais elaboraram leis mais ou menos restritivas que regulam o aborto. Desde maio de 2019, alguns Estados americanos têm restringido consideravelmente a possibilidade de realizar o aborto em seu território. Alabama praticamente proibiu o aborto em qualquer circunstância (incluindo incesto e estupro). $\mathrm{Ob}$ viamente, estas politicas restritivas tiveram um impacto significativo no debate social, bioético e jurídico, a nível mundial, sobre o aborto. Este artigo analisa as implicações dessas políticas com foco nos direitos fundamentais da mulher: o direito à saúde e o direito à autodeterminação.

Palavras-chave Aborto, Restrição do aborto, Política de saúde, Mulheres, Feto 


\section{Introduction}

Induced abortion is defined as the termination of pregnancy before the time of fetal viability. There are several methods that can be used to induce abortion: medical or surgical. Medical abortion is a non-surgical method used to terminate pregnancy, usually in the first trimester; the most used drugs for medical abortion are progesterone antagonist (such as mifepristone) and/or with prostaglandin $\mathrm{E}$ analogue (such as misoprostol). These drugs are able to induce an abortion in total safety for the woman with a low incidence of side effects and excellent outcome ${ }^{1,2}$.

The regulation of voluntary termination of pregnancy varies according to the local legislation of the Member States. The World Health Organization (WHO), in 2012, recommended that it be made possible for all women to have recourse to abortion safely and legally, recognizing this procedure as a woman's right ${ }^{3}$.

In the US, after a famous 1973 Supreme Court ruling (Roe $\mathrm{v}$ Wade ${ }^{4}$ ), abortion became legal. The debate on abortion, as in the rest of the world, has remained unresolved and there are still many anti-abortion positions today which, in fact, recently led, in Alabama, to the entry into force of a law prohibiting abortion in any circumstance ${ }^{5}$. Although the regulation of abortion in Alabama is the most stringent, there is also some discussion in other states in the US about the possibility of legally restricting abortion. In fact, for example, on 30 May 2019, a law came into force in Louisiana prohibiting abortion at the time when the fetus's heartbeat is detectable (6 weeks gestation $)^{6}$; also, in Georgia, Mississippi, Iowa, Kentucky and Ohio have been drafted laws prohibiting abortion from the moment it is possible to detect the fetal heartbeat (so-called "heartbeat" Bill); in Missouri, from 24 May 2019, it has become illegal to abort after 8 weeks of pregnancy, even in cases of incest or rape; Utah and Arkansas similarly passed a law that bans abortion after 18 weeks' gestation ${ }^{7}$.

This wave of abortion bans in the US has, of course, also international resonance and the consequences - on the social, bioethical and medico-legal debate - are global. In the world, between 2010 and 2014, 1 in 4 pregnancies were interrupted by induced abortion; therefore, the health policies related to this widespread procedure have a significant impact on women's lives 8 .

\section{Risk of discrimination and unsafe abortion}

With the entry into force of these laws, women with lower incomes, minors, migrants, etc. have inevitably been affected, because this category of women have much more difficulty in paying, absentee from work and travel to countries where abortion is permitted. After these laws, performing an abortion will probably become more difficult and dangerous, with the risk of increasing illegal abortions in unsafe conditions for the woman. This situation will have a further impact on the already more affected African American women who, already today, are much more likely to die during pregnancy or delivery than white women'.

$45 \%$ of induced abortions performed During 2010-2014 were unsafe. In particular, $14 \%$ of induced abortions carried out in this period did not even respect a WHO-recommended method, with considerable risks to the lives of women ${ }^{8}$.

In developing countries, due to the difficulty of access to health facilities where safe abortion is performed, mortality rates for unsafe abortion is very high ${ }^{10}$. The most frequent causes of death are genital trauma, infection and sepsis ${ }^{11}$. In addition, the possibility of dying from unsafe abortion in countries with restrictive abortion policies is much higher than in countries with liberal abortion policies ${ }^{12}$, thus, as also highlighted by the WHO, the permissiveness of abortion laws is inversely proportional to deaths unsafe abortion related ${ }^{13}$. It is clear that abortion is a safe procedure only if it is easily available to women who request it and only if it is made accessible to all though the adequate and advanced public health policies. On the contrary, denying a woman the possibility of abortion means making her a victim of discrimination and exposing her to the risks associated with unsafe abortion. Indeed, it is important to stress that the right to abortion, like the right to receive any other medical act, cannot be denied, especially if the potential consequence of this prohibition is the predictable and avoidable death of women.

\section{The Rights of the Women and the Rights of the Fetus}

On the basis of the right to self-determination and the right to health, it can be stated that women have the right to abortion if they so wish. It could be said that the management of the uterus, being an organ in the woman's organism, 
belongs to the patient and not to third persons. Therefore, as with any other medical treatment, the choice inherent in abortion is the exclusive prerogative of the pregnant individual. For this reason, without doubt, women's right to self-determination should be protected by health policies and state laws. Nevertheless, decisions on the fate of one's own body in relation to pregnancy are subject to the opinions and choices of others, greatly limiting the right to self-determination of the woman herself. The importance of the right to decide in full conscience and freedom was also highlighted by a ruling of the Italian Court of Cassation in $2018^{14}$ in which compensation was awarded to a woman who had expressed a desire to terminate her twin pregnancy; however, due to a medical error, the abortion concerned only one fetus. The judges have recognized the compensation both for the damage to the psycho-physical health of the woman, and for the damage caused to both the parents for the lesion of the freedom of self-determination. Even American federal judges have momentarily blocked the anti-abortion laws enacted in Mississippi, Missouri, Utah, Iowa and Kentucky stating that banning abortion after $6^{\text {th }}$ week of gestation could undermine women's right to carry out a free choice focused on full dignity and autonomy; thus "heartbeat law", on abortion restriction, was declared unconstitutional ${ }^{15-17}$.

On the other hand, it is important to also outline the possible rights of the fetus in relation to abortion. Convention on the Rights of the Child affirm that the child, by reason of his physical and mental immaturity, needs special safeguards and care, including appropriate legal protection, before as well as after birth ${ }^{18}$. The concept of child is ambiguous and, clearly, the alleged right of the unborn would conflicts with the right of a pregnant woman to have an abortion. To try to resolve this conflict it will be necessary to understand when a foetus becomes a child (therefore an individual). To date, the debate on when the fetus becomes a human being with all its rights is still unresolved. Several stages of fetal development can be taken as a benchmark: conception, implantation, tissue separation, brain activity, viability of the fetus, birth. There's no agreement as to what stage of fetal development should be associated with the right to life $\mathrm{e}^{19}$.

It is considered that in the absence of viability of the fetus, the possible right to life of a potential human being cannot be privileged over the right to health and self-determination of an already born individual.

\section{Desirable policies}

Rather than restricting access to abortion or even prohibiting it, it would be beneficial to implement policies that aim at preventing unwanted pregnancies. First of all, it is essential to implement sexual education programmes in schools in order to raise awareness among young women and men not only on the issue of abortion but also on the problems related to sexually transmitted diseases associated with unprotected sexual practices. Moreover, policies aimed at increasing the use of contraceptives would be very useful. This requires both awareness-raising policies and policies that increase the global availability of contraceptives. Contraception is a key tool for reducing the demand for abortion. In fact, most abortions are performed by women who did not want to get pregnant and who used incorrectly, did not use or could not use contraceptives. In developing countries, $84 \%$ of unintended pregnancies concern women who have not had access to modern contraception tools ${ }^{20}$.

Health policies aimed at counseling on pregnancy options, early gestational ultrasonography etc. are also desirable. Finally, it is essential to guarantee all women, of any social background, of any ethnicity, of any age, access to abortion which should be considered an essential health care. To do this it is necessary to ensure that in every hospital there is at least one gynecologist who is not a conscientious objector; otherwise there is a risk that abortion will become a privilege for rich women or women with nearby and better organized hospitals.

\section{Conclusion}

Abortion will always be a bioethically and legally debated procedure. Nevertheless, there are inalienable rights for which politics and scientific community must always fight. One of these rights is to the self-determination of women which is too often questioned by religious and/or social opinions. To try to solve bioethical issues related to the topic of abortion it will be essential to define scientifically when a fetus can be considered a human being with the right to life. In the expectation of a scientific response, to date, it can be said that - in the medical procedure of abortion women are the only human beings (from a medico-legal point of view) involved and, therefore, it is necessary to protect their inalienable rights of freedom, health and self-determination, regard- 
less of their country of origin, social background or ethnic group.

\section{References}

1. Soon JA, Costescu D, Guilbert E. Medications Used in Evidence-Based Regimens for Medical Abortion: An Overview. J Obstet Gynaecol Can 2016; 38(7):636-645.

2. Costescu D, Guilbert E, Bernardin J, Black A, Dunn S, Fitzsimmons B, Norman WV, Pymar H, Soon J, Trouton K, Wagner MS, Wiebe E, Gold K, Murray MÈ, Winikoff B, Reeves M, Society of Obstetricians and Gynecologists of Canada. Medical Abortion. J Obstet Gynaecol Can 2016; 38(4):366-389.

3. World Health Organization (WHO). Safe abortion: technical and policy guidance for health systems. $2^{\text {nd }} \mathrm{ed}$. Geneva: WHO; 2012.

4. Justia US Supreme Court. Roe v. Wade, 410 U.S. 113 (1973) [Internet]. [cited 2019 Nov 26]. Available from: https://supreme.justia.com/cases/federal/us/410/113/.

5. Dyer O. Alabama law makes almost any abortion a crime. BMJ 2019; 365:12232.

6. Louisiana Law. Act No. 31. Senate Bill No. 184 [Internet]. 2019 [cited 2019 Nov 26]. Available from: http://www.legis.la.gov/legis/ViewDocument.as$\mathrm{px} ? \mathrm{~d}=1140119$.

7. Guttmacher Institute. An Overview of Abortion Laws [Internet]. 2019 [cited 2019 Nov 26]. Available from: https:/www.guttmacher.org/state-policy/explore/ overview-abortion-laws.

8. Guttmacher Institute. Induced abortion worldwide: Global incidence and trends [Internet]. 2018 [cited 2019 Nov 26]. Available from: https://www.guttmacher.org/fact-sheet/induced-abortion-worldwide.

9. Amnesty International. Deadly Delivery. The Maternal Health Care Crisis in the USA [Internet]. 2010 [cited 2019 Nov 26]. Available from: https://www.amnestyusa.org/files/pdfs/deadlydelivery.pdf.

10. Haddad LB, Nour NM. Unsafe abortion: unnecessary maternal mortality. Rev Obstet Gynecol 2009; 2(2):122-126.

11. World Health Organization (WHO). Unsafe Abortion: Global and Regional Estimates of the Incidence of Unsafe Abortion and Associated Mortality in 2003. $5^{\text {th }} \mathrm{ed}$. Geneva: WHO; 2007.

12. United Nations. Department of Economic and Social Affairs, Population Division. Abortion Policies and Reproductive Health around the World. New York: United Nations Publication; 2014.

13. World Health Organization (WHO). Primary Health Care: Now More than Ever. World Health Report 2008. Geneva: WHO; 2008.

\section{Collaborations}

A Cioffi conceived and designed the article and drafted the manuscript. F Cioffi revised the article critically. R Rinaldi supervised the work. All authors read and approved the final manuscript.

14. Corte Suprema di Cassazione. Ordinanza 29 gennaio 2018, n. 2070 [Internet]. 2018 [cited 2019 Nov 26]. Available from: https://www.altalex.com/documents/ news/2018/01/31/nascita-indesiderata-diritto-di-decidere-in-piena-coscienza-e-liberta-va-tutelato.

15. New York Times. Federal Judge Blocks Mississippi Abortion Law [Internet]. 2019 [cited 2019 Nov 26]. Available from: https://www.nytimes.com/2019/05/24/us/ mississippi-abortion-law.html.

16. CNN. Iowa's 'fetal heartbeat' abortion restriction declared unconstitutional [Internet]. [cited 2019 Nov 26]. Available from: https://edition.cnn.com/2019/01/23/ us/iowa-fetal-heartbeat-abortion-unconstitutional/ index.html.

17. Los Angeles Times. Kentucky abortion law is struck down by a federal judge [Internet]. [cited 2019 Nov 26]. Available from: https://www.latimes.com/ nation/nationnow/la-na-kentucky-abortion-law20190510-story.html.

18. United Nations Human Rights. Convention on the Rights of the Child. Adopted and opened for signature, ratification and accession by General Assembly resolution 44/25 of 20 November 1989 entry into force 2 September 1990, in accordance with article 49 [Internet]. [cited 2019 Nov 26]. Available from: https://www.ohchr.org/en/professionalinterest/pages/crc.aspx.

19. Cioffi A, Cioffi F. A foetus during labour is legally a human being. Med Sci Law 2020; 60(2):161-162.

20. Guttmacher Institute. Adding It Up: Investing in Contraception and Maternal and Newborn Health [Internet]. 2017 [cited 2019 Nov 26]. Available from: https://www.guttmacher.org/fact-sheet/adding-it-upcontraception-mnh-2017.

Article submitted 12/04/2020

Approved 21/04/2020

Final version submitted 23/04/2020

Chief editors: Romeu Gomes, Antônio Augusto Moura da Silva 